\title{
indemnity
}

\section{LIFE AFTER REGISTRATION}

Kevin Lewis, Dental Director of Dental

Protection, explains some of the less obvious

consequences of registration of $\mathrm{PCDs}$,

including professional

indemnity

considerations.

\section{W} remote and uninhabited pacific island durjungle 20 years later, unaware that the war had ended. I always wondered if he ever got his back-pay.

The British dental profession has somehing of a reputation for taking precious little interest in dental politics, although in fairness it has become almost a full time occupation to keep up-to-date with the uge number of changes in the NHS, at the DC and in areas such as employment law. suspect, however, that there are more than a few PCDs, as well as dentists, for whom all the current changes are events taking place on the other side of the jungle, so to peak. When they eventually emerge there will certainly be a shock awaiting them. The General Dental Council (GDC) is required by law, under the Dentists Act, to maintain a register of all dentists who are entitled to carry out the practice and business of dentistry here in the UK. A similar process has existed for some time in respect of hygienists and therapists, who hav needed to be 'enrolled' with the GDC they wished to practise in the UK. Nurses and technicians will likely face registration in 2004

The practical consequences of this registration process may not be immediately obvious, but they are certainly far-reach-
ing. The Council needs to be involved in ing. The Council needs to be involved in evaluating the standards of UK training onces what is known as self-regulation. Some PCDs have started to ask what registration will mean for them personally and professionally, and in particular, whether professional indemnity in their own right, just like dentists do

Many dentists, hygienists and therapists, believe that the main purpose of having professional indemnity is to protect themselves against the financial consequences of negligence claims against them. In the UK, these groups of healthcare professionals have traditionally become members of protection/defence organisations. These are non-profit-making mutual societies, all of whose funds are owned by the members themselves, as opposed to profit-making insurance companies which might need to serve the interests of shareholders as a first priority. The benefits of membership of a protection/defence society include (but are certainly not limited to) the payment of damages, legal costs and associated expenses on behalf of the member concerned. Once you are registered with the GDC, whole new spectrum of accountability and responsibility arises. Having someone trained and experienced in dento-legal matters, available to talk to, or to help you to prepare a response to a letter from the $\mathrm{GDC}$, and/or someone to represent you at an investigation or hearing, is obviously invaluable.

Once you are registered, you can't shru your shoulders and blame your employer, or the practice owner, or the manager of a hospital or trust where you are working. If,
for example, you are working in an environment whe

control are inadequate, you can no longer stand by if patients are being placed at risk ou have a personal responsibility to do omething about it, and if you fail to do so you can expect to be personally answerable the GDC

You might become involved in complaints Ciminal allegations or disciplinary investigatons regarding radiation safety or other aspects of Health and Safety (for example, 保ure to segregate clinical waste or dispose fely of sharps), or for your part in making -knowingly or unknowingly - inappropriate 列 islead or deceive a patient regarding the tment they are receiving. Criticising the or others, or breaches of confidentiali/data protection are other examples of eas where anyone who is registered with

Registration brings many privileges, but with them come new reponsibilities. Keeping up-to-date, participating in continuing professional development, bein prepared to take personal responsibility for ne's own acts and omissions, and mainaining the high ethical standards that the public has a right to expect, is all part of the package that includes a more central an respected position in the profession. hould be seen as an opportunity, not hreat. Being part of a more integrated an cohesive expanded dental team should create a richer and more fulfilling role in the provision of dental care. The greate accountability can seem a bit scary at firs, but it is a price well worth paying for the opportunity of taking down some of the barriers that have existed in the past. 